\title{
OPIEKA PIELĘGNIARSKA NAD PACJENTKĄ Z RAKIEM SUROWICZYM JAJNIKA PO ZABIEGU OPERACYJNYM - STUDIUM PRZYPADKU
}

\section{NURSING CARE OF THE PATIENT WITH SEROUS OVARIAN CANCER AFTER SURGERY - CASE STUDY}

Iwona Włodek, Anna Zera, Andrzej Krupienicz

Zakład Podstaw Pielęgniarstwa

Warszawski Uniwersytet Medyczny

DOI: https://doi.org/10.20883/pielpol.2017.47

\section{STRESZCZENIE}

Założenia. W Polsce nowotwory złośliwe jajnika stanowią u kobiet ok. 5\% zachorowań. Późne rozpoznanie skutkuje wysoką śmiertelnością, co sprawia, że rak jajnika jest najtrudniejszym problemem ginekologii onkologicznej. W leczeniu kluczową rolę odgrywa leczenie operacyjne. Okres hospitalizacji wiąże się z wystąpieniem licznych problemów pielęgnacyjnych. Niezbędny jest zarówno nadzór po zabiegu, pomoc w zapewnieniu potrzeb biologicznych, jak i wsparcie psychiczne, odgrywające znaczącą rolę w leczeniu chorób nowotworowych.

Prezentacja przypadku. Celem pracy było przedstawienie problemów pacjentki z rakiem surowiczym jajnika po zabiegu operacyjnym oraz zaplanowanie opieki pielęgniarskiej nad chorą.

Wyniki. Jakość opieki po interwencji chirurgicznej zależała przede wszystkim od personelu pielęgniarskiego. Dzięki rzetelnej opiece zmniejszono ryzyko groźnych powikłań. Zapewnienie profesjonalnej opieki pooperacyjnej wpłynęło na przebieg dalszego procesu leczenia i poprawiło jakość życia chorej. Wnikliwa obserwacja i szybka reakcja pielęgniarki umożliwiła pacjentce szybki powrót do sprawnego i samodzielnego funkcjonowania.

SŁOWA KLUCZOWE: opieka pooperacyjna, rak jajnika.

\section{Wprowadzenie}

W Polsce nowotwory złośliwe jajnika stanowią u kobiet ok. 5\% zachorowań. W 2013 roku odnotowano ich 3639, co powoduje, iż rak jajnika jest piątym co do częstości występowania nowotworem złośliwym [1, 2]. Późne rozpoznanie skutkuje wysoką śmiertelnością, co sprawia, że rak jajnika jest najtrudniejszym problemem ginekologii onkologicznej. Przeżycia 5-letnie wynoszą 30-40\% w stadiach III i IV wg FIGO (Międzynarodowa Federacja Ginekologii i Położnictwa). We wczesnych stadiach są wyższe i wynoszą 80-90\% [3]. Do wystąpienia omawianej patologii predysponuje nosicielstwo mutacji genów BRCA1 lub BRCA2, wiek - po 45 r.ż., brak porodów, niepłodność, stosowanie hormonalnej terapii zastępczej

\begin{abstract}
Assumptions. In Poland, ovarian cancer among women constitutes approx. $5 \%$ of cases. A late diagnosis results in high mortality, which makes ovarian cancer the most difficult problem of gynecological oncology. In the treatment surgery plays the key role. The period of hospitalization is associated with the occurrence of a number of nursing problems. Supervision after surgery, help in providing biological and psychological needs, as well as psychological support play a significant role in cancer treatment. Presentation of the case. The aim of the study was to present problems of patients with serious ovarian cancer after surgery and plan their nursing care.

Results. Quality of care after the surgery depends mainly on the nursing staff. With reliable care risk of serious complications is reduced. Providing professional postoperative care influences the course of the further process of treatment and improves quality of life for the patient. Careful observations and rapid nurse's response enables the patient to recover quickly.
\end{abstract}

KEYWORDS: post-operative care, ovarian cancer.

[4]. Nowotwory złośliwe jajnika najczęściej mają pochodzenie nabłonkowe (ok. 80\%). Typ surowiczy rozwija się z nabłonka pokrywającego strzępki jajowodu, ten implantowany jest w jajniku w miejscu, gdzie znajduje się ubytek po owulacji [5]. Wczesne stadia raka jajnika nie są związane z żadnymi charakterystycznymi objawami klinicznymi. Zaawansowane postacie manifestują się uczuciem zmęczenia, bólem w miednicy mniejszej, zmianą masy ciała i wzdęciami [6]. Postępowanie diagnostyczne obejmuje badanie ginekologiczne oraz badania obrazowe - badanie ultrasonograficzne (USG), tomografii komputerowej (TK), rezonansu magnetycznego (MR), pozytonowej tomografii emisyjnej (PET) [7]. Marker nowotworowy CA 125 wykorzystywany jest do 
ustalenia rozpoznania, monitorowania skuteczności leczenia i wczesnego rozpoznana wznowy raka jajnika. Jego stężenie jest podwyższone w ok. $80 \%$ raków surowiczych jajnika [8]. W leczeniu kluczową rolę odgrywa postępowanie chirurgiczne. Ma na celu uzyskanie materiału tkankowego do potwierdzenia diagnozy, ocenę stopnia rozprzestrzenienia się nowotworu w jamie brzusznej oraz uzyskanie maksymalnej redukcji nowotworu [9]. Zmniejszenie masy guza o każde 10\% wydłuża czas przeżycia o 5,5\%. Leczenie operacyjne kojarzone jest z chemioterapią. Najczęściej jest to terapia dwulekowa, składająca się z paklitakselu i karboplatyny [10]. Okres hospitalizacji wiąże się z wystąpieniem licznych problemów pielęgnacyjnych. Niezbędny jest zarówno nadzór po zabiegu, pomoc w zapewnieniu potrzeb biologicznych, jak i wsparcie psychiczne, odgrywające znaczącą rolę w leczeniu chorób nowotworowych. Kontroli podlegają: świadomość pacjentki, parametry życiowe, diureza, wartości morfotyczne krwi, stężenia elektrolitów, wskaźniki równowagi kwasowozasadowej, jak i opatrunki, drenaże rany pooperacyjne. Od zespołu pielęgniarskiego wymaga się dużej wiedzy, umiejętności, empatii i zrozumienia, aby ustrzec chorą przed groźnymi powikłaniami [11].

Celem pracy było przedstawienie problemów pacjentki z rakiem surowiczym jajnika po zabiegu operacyjnym oraz zaplanowanie opieki pielęgniarskiej nad chorą.

\section{Opis przypadku}

56-letnia kobieta została przyjęta na oddział ginekologiczno-położniczy warszawskiego szpitala 27.03.15. w trybie planowym w celu wykonania laparotomii. Dziesięć lat temu u pacjentki zdiagnozowano nadciśnienie tętnicze, kontrolowane i leczone farmakologicznie (Tertensif 1x1,5mg). Pacjentka w wieku 25 i 29 lat przebyła dwa porody fizjologiczne (ciąże i okresy połogu przebiegły prawidłowo). W wywiadzie zgłaszała nieregularne cykle miesiączkowe. Kobieta menopauzę przeszła w 52. r.ż. Nie podawała chorób nowotworowych w wywiadzie rodzinnym. Od roku odczuwała okresowe bóle brzucha, wzdęcia. Miała też znacznych rozmiarów hemoroidy w okolicy odbytu. W październiku 2014 r. rutynowo wykonywane badania laboratoryjne krwi wykazały podwyższenie D-dimerów (wartość 2400 g/l). Szczegółowa diagnostyka obrazowa oraz oznaczenie CA125 ujawniło chorobę nowotworową w obrębie jajnika prawego. Został on usunięty w grudniu 2014 r. Dnia 29.12.14 uzyskano wynik badania histopatologicznego-rak surowiczy jajnika IIIC G3, rozsiany proces nowotworowy. Dnia 31.12.14 chora przyjęła pierwszy kurs chemioterapii neoadiuwantowej według programu Karboplatyna z Taxolem. Dnia 30.03.15 operowana - wykonano lapa- rotomię w znieczuleniu chirurgicznym ogólnym. Z cięcia pośrodkowego dokonano usunięcia macicy z przydatkami lewymi, biopsji węzłów chłonnych miedniczych obustronnie oraz węzłów chłonnych okołoaortalnych, biopsji sieci większej, pobrano wymazy spod kopuł przepony.

Opieka pielęgniarska nad chorą obejmowała wczesny okres pooperacyjny, tj. 24 godziny od momentu zakończenia operacji. Pacjentka miała opatrunek na jamie brzusznej od wyrostka mieczykowatego do spojenia łonowego oraz dren Redona wyprowadzony z rany pooperacyjnej. Posiadała wkłucie obwodowe w żyle grzbietu dłoni. Do momentu powrotu perystaltyki otrzymywała płyny dożylne zgodnie ze zleceniem lekarskim (PWE $2 x$ $500 \mathrm{ml}$ i.v., 0,9\% $\mathrm{NaCl} 2$ x $500 \mathrm{ml}$ i.v., 5\% roztwór glukozy $500 \mathrm{ml}$ i.v.). Utrzymany był cewnik Foleya - $2000 \mathrm{ml}$ moczu. Chora po interwencji chirurgicznej pozostawała w łóżku, z powodu bólu niechętnie podejmowała próby poruszania się. Leki przeciwbólowe podawano według zlecenia lekarza (Ketonal 3 x 50 mg i.v., Pyralgin $3 \times 1 \mathrm{~g}$ i.v., Morphini sulfas WZF 2 mg i.v. w razie bólu). Kontynuowano profilaktykę przeciwzakrzepową (zachęcanie do zmiany pozycji, Clexane s.c. 1 x 0,04 mg). Kontakt logiczno-słowny z chorą był dobry. Rozumiała konieczność pobytu w szpitalu. Była zaniepokojona swoim stanem zdrowia i dalszym postępowaniem.

Osiem głównych problemów, z jakimi miał do czynienia personel pielęgniarski w trakcie opieki pooperacyjnej nad pacjentką, opisano poniżej:

\section{Unieruchomienie pacjentki z powodu bólu rany} pooperacyjnej, osłabienia, obecności drenażu

Cel opieki: zapewnienie potrzeb biologicznych, zniwelowanie bólu, uruchomienie pacjentki.

Plan działania: określenie potrzeb, ocena zdolności chorej w zakresie samoopieki, pomoc przy wykonaniu toalety ciała, prześcieleniu łóżka, zmiana bielizny osobistej, pościelowej, zapewnienie intymności, zapewnienie odpowiedniego mikroklimatu (wietrzenie sali, temperatura $20^{\circ} \mathrm{C}$ ), ułożenie pacjentki w pozycji zmniejszającej napięcie rany pooperacyjnej (ułożenie na plecach z tułowiem uniesionym wyżej - pod kątem $30^{\circ}$, pod kolanami umieścić wałek, pod karkiem małą poduszkę), zwalczanie bólu pooperacyjnego (ocena bólu za pomocą skali VAS-Visual Analogue Scale, systematyczna podaż leków przeciwbólowych na zlecenie lekarza, szybkie reagowanie na objawy bólu - manifestowane werbalnie i pozawerbalnie, poprzez zmiany parametrów życiowych, tj. wzrost ciśnienia tętniczego, przyspieszenie tętna, przyspieszenie, spłycenie oddechu, nadmierną potliwość, zaniepokojenie, minimalizacja ruchów ciała), współudział w gimnastyce oddechowej torem piersiowym ze stabilizacją rękami okolic rany pooperacyjnej (w pozycji półsiedzącej nauka prawidłowego 
oddechu, uwzględniająca jego fazy, tj. wdech krótki, głęboki nosem, długi wydech ustami, stosunek wdech:wydech 1:3, oraz ćwiczenia oddechowe oporowe z wykorzystaniem butelki z wodą i rurką - nabranie powietrza nosem, wydmuchanie przez rurkę do butelki ok. 3 powtórzenia 3-5 razy dziennie, następnie ćwiczenia efektywnego kaszlu - wdech nosem, długi wydech ustami, zakończony kaszlem lub wymawianiem głoski „h”), wczesne uruchamianie, stopniowa rehabilitacja (aktywizacja w obrębie łóżka, ćwiczenia mobilizujące krążenie obwodowe, np. rytmiczne zgięcia podeszwowe, grzbietowe stóp, siadanie w łóżku, siadanie z opuszczonymi nogami z jednoczesną kontrolą czynności akcji serca i ciśnienia tętniczego) [12, 13, 14].

Ocena działań: zminimalizowano ból, nastąpiła poprawa samopoczucia, zapewniono czystość, uruchomiono pacjentkę w obrębie łóżka.

2. Ból rany operacyjnej z powodu ucisku opatrunku, zastosowania szwów, urazu nerwów somatycznych

Cel opieki: likwidacja bólu.

Plan działania: ułożenie pacjentki w pozycji zmniejszającej napięcie rany pooperacyjnej (j.w.), obserwacja charakteru i natężenia dolegliwości bólowych (użycie skali VAS), zastosowanie środków przeciwbólowych według zlecenia lekarskiego, obserwacja i reagowanie na objawy werbalne i pozawerbalne odczuwania bólu (j.w.), wykonywanie zabiegów pielęgnacyjnych po podaniu leków przeciwbólowych, zastosowanie niefarmakologicznych metod podnoszenia progu bólowego (zapewnienie spokoju, wypoczynku, odwrócenie uwagi, rozmowy z chorą, relaksacja) i łagodzenia bólu (psychoterapia elementarna, komunikacja niewerbalna z chorą, stworzenie atmosfery bezpieczeństwa, życzliwości), ocena skuteczności leczenia przeciwbólowego (użycie skali VAS, ocena parametrów życiowych) [12, 14].

Ocena działań: zminimalizowano ból, zapewniono wygodę pacjentce, nastąpiła poprawa samopoczucia.

\section{Ryzyko wystąpienia krwotoku z powodu zabie- gu operacyjnego}

Cel opieki: wczesne wykrycie objawów krwotoku, podjęcie działań, mających zapewnić chorej bezpieczeństwo.

Plan działania: ocena świadomości, monitorowanie parametrów życiowych-tętna, ciśnienia tętniczego, oddechów (co 15 minut przez pierwsze 2 godz., co 30 min przez 4 godz., co 1 godz. do upływu pierwszych 12 godz., później co 2 godz.), obserwacja opatrunku na ranie pooperacyjnej w kierunku przesiąkania wydzieliną (co 15 min przez pierwszą godzinę, przez kolejne 2 co $30 \mathrm{~min}$, następnie co 60 min oraz po kaszlu i wymiotach), obserwacja ilości, rodzaju wydzieliny w drenażu (w pierwszej dobie powinna być krwista i <100 ml), obserwacja koloru, wilgotności skóry (sinoszare zabarwienie na palcach, wargach świadczy o niedotlenieniu, szybkość powrotu kapilarnego powinna wynosić 1-2 sekundy, wydłużenie może oznaczać stan hipowolemii i niedotlenienia), obserwowanie zachowania, nastroju pacjentki (np. zawroty głowy, mroczki przed oczami), zgłoszenie lekarzowi niepokojących objawów [11].

Ocena działań: nie zaobserwowano objawów krwotoku.

4. Ryzyko zakażenia rany pooperacyjnej lub w miejscu założenia drenu, na skutek zmniejszonej odporności chorej, kolonizacji flory bakteryjnej

Cel opieki: zmniejszenie ryzyka zakażenia, wczesne jego wykrycie.

Plan działania: zapewnienie higieny osobistej i otoczenia, obserwacja rany w kierunku cech zapalenia (obrzęk, zaczerwienienie brzegów rany, ból, gorączka - kontrola ciepłoty ciała 2 razy dziennie), zmiana opatrunku kilkanaście godzin po operacji (wcześniej zmienia się mocno przesiąknięty) zgodnie z zasadami aseptyki, antyseptyki, obserwacja ilości, charakteru wydzieliny z drenu (alarmujące jest nagromadzenie 50-100 ml/h krwistej wydzieliny), zabezpieczenie drenu przed mechanicznym drażnieniem, zaginaniem, wymiana pojemników połączonych z drenem raz dziennie, utrzymanie ich poniżej poziomu łóżka [15].

Ocena działań: brak cech zakażenia, problem wymaga dalszej kontynuacji działań.

5. Możliwość wystąpienia choroby zakrzepowo-zatorowej z powodu unieruchomienia

Cel opieki: niedopuszczenie do rozwinięcia się choroby zakrzepowo-zatorowej.

Plan działania: wprowadzenie profilaktyki przeciwzakrzepowej przed operacją (zastosowanie pończoch elastycznych, podawanie heparyny drobnocząsteczkowej według zlecenia lekarza), wykonywanie ćwiczeń biernych i czynnych kończyn dolnych, gdy chora pozostaje w łóżku (uniesienie kończyn dolnych powyżej poziomu serca, krążenie stóp, wykonywanie co godzinę 20 rytmicznych zgięć grzbietowych, podeszwowych stóp, 10 zgięć kończyn dolnych w stawach kolanowych, biodrowych bez unoszenia stóp), wczesne uruchomienie pacjentki (w pierwszej dobie po zabiegu podjąć próbę krótkiej pionizacji, kontrolując czynność układu krążenia i eliminując pracę mięśni brzucha: chora najpierw układa się na boku, przesuwa podudzia poza łóżko, opierając się na kończynach górnych unosi tułów, siada z opuszczonymi nogami, następnie wstaje z asekuracją) $[11,12]$

Ocena działań: brak cech choroby zakrzepowo-zatorowej, wcześnie uruchomiono chorą. 


\section{Ryzyko zakażenia układu moczowego z powo- du założonego cewnika Foleya}

Cel opieki: niedopuszczenie do zakażenia, wczesne wykrycie objawów zakażenia.

Plan działania: higiena okolicy ujścia cewki moczowej, obserwacja miejsca założenia cewnika w kierunku infekcji (ból, pieczenie okolicy cewki moczowej, ból okolicy nadłonowej, gorączka), umieszczenie zbiornika na mocz poniżej pęcherza moczowego, kontrola ilości i zabarwienia moczu co godzinę (norma to minimum $100 \mathrm{ml} / \mathrm{h}$ klarownego, słomkowożółtego moczu), zapewnienie odpowiedniej podaży płynów, usunięcie cewnika po 2 dobach przy prawidłowej diurezie [15].

Ocena działań: brak cech zakażenia, problem wymaga dalszej kontynuacji działań.

\section{Ryzyko zakażenia z powodu założonego wkłu- cia obwodowego}

Cel opieki: niedopuszczenie do zakażenia, wczesne wykrycie objawów zakażenia.

Plan działania: zapewnienie higieny osobistej, obserwacja miejsca wkłucia pod kątem cech zapalenia (zaczerwienienie, obrzęk, ból, gorączka), wymiana wkłucia co $72 \mathrm{~h}$, zmiana okleiny raz dziennie lub gdy jest wilgotna lub zabrudzona, zabezpieczenie wkłucia jałowym koreczkiem, wymienianym po każdej manipulacji przy wkłuciu, przestrzeganie zasad aseptyki, antyseptyki [15].

Ocena działań: brak cech zakażenia, problem wymaga dalszej kontynuacji działań.

\section{Obniżony nastrój wynikający $z$ rozpoznania choroby, lęk przed konsekwencjami leczenia}

Cel opieki: poprawa nastroju, zniwelowanie lęku.

Plan działania: określenie zapotrzebowania na wsparcie, stworzenie atmosfery bezpieczeństwa, informowanie o czynnościach wykonywanych wokół chorej, mobilizowanie do aktywnego współdziałania w procesie terapii, budowanie nadziei, wyjaśnienie wątpliwości, umożliwienie kontaktu z innymi pacjentkami po operacji, psychologiem, osobą duchowną [11].

Ocena działań: nastąpiła poprawa nastroju pacjentki, wytworzono pozytywny stosunek do leczenia operacyjnego.

\section{Dyskusja}

Opisany przypadek pokazał, iżjakość opieki po interwencji chirurgicznej zależała przede wszystkim od personelu pielęgniarskiego. Pielęgniarka wypełniając funkcje zawodowe wspierała chorą w najtrudniejszym okresie życia. Pacjentka oprócz profesjonalnej opieki miała zapewnioną także edukację, aby zdobyć odpowiednią wiedzę i nabyć umiejętności praktyczne niezbędne do samoopieki. Dzięki rzetelnej opiece zmniejszono ryzyko groźnych powikłań, takich jak krwotok zewnętrzny, wstrząs, ostra niewydolność krążenia, niewydolność nerek, obrzęk płuc. Dalsze postępowanie obejmowało monitorowanie stanu ogólnego 3 razy dziennie, kontynuowanie nawadniania dożylnego $z$ jednoczesną kontrolą ciśnienia tętniczego i tętna w celu zapobiegania objawom hipowolemii. Kontrolowano efekt przeciwbólowy, kontynuowano farmakoterapię, obserwowano sferę somatyczną i psychiczną chorej w kierunku powikłań leczenia przeciwbólowego i braku jego skuteczności. W kolejnych dobach należało zmieniać opatrunki na ranie pooperacyjnej, kontrolować stan rany, po 2-3 dniach usunąc dren Redona, po 7 dniach szwy. Przy prawidłowej diurezie po 2 dniach usunąć cewnik Foleya. Pielęgniarka odpowiadała też za dalszą rehabilitację układu oddechowego, krążenia i kostno-stawowego. Zapewnienie profesjonalnej opieki pooperacyjnej wpłynęło na przebieg dalszego procesu leczenia i poprawiło jakość życia chorej. Wnikliwa obserwacja i szybka reakcja pielęgniarki umożliwiły pacjentce powrót do sprawnego i samodzielnego funkcjonowania. Wszystkie te działania wykazały, iż pielęgniarka jest niezbędnym ogniwem interdyscyplinarnego zespołu terapeutycznego.

\section{Piśmiennictwo}

1. Panek G. Nowotwory - wprowadzenie http://onkologia.org. $\mathrm{pl} /$ nowotwory-wprowadzenie/ (data dostępu: $16.12 .15 \mathrm{r}$.)

2. Zakład Epidemiologii i Prewencji Nowotworów Centrum Onkologii - Instytut w Warszawie. Raport na podstawie danych Centrum Onkologii, http://85.128.14.124/KRN/liczba_zach_ rozp/default.asp (data dostępu: 16.12.15 r.)

3. Markowska A. Epidemiologia i etiopatogeneza raka jajnika. W: Markowska J, Mądry R (red.). Zarys ginekologii onkologicznej. Tom II. Poznań: Termedia; 2012. 209-217.

4. Markowska A, Markowska J. Epidemiologia raka jajnika na świecie i w Polsce. Etiopatogeneza. W: Wcisło G, Szczylik C (red.). Rak jajnika. Patobiologia, diagnostyka i przegląd współczesnych metod leczenia. Poznań: Termedia; 2011. 139-147.

5. Korski K. Histopatologia raka jajnika. W: Markowska J, Mądry R (red.). Zarys ginekologii onkologicznej. Tom II. Poznań: Termedia; 2012. 219-226.

6. Manyś G. Objawy raka jajnika. W: Markowska J. Mądry R (red.). Zarys ginekologii onkologicznej. Tom II. Poznań: Termedia; 2012. 249-252.

7. Gosek P. Diagnostyka i profilaktyka w raku jajnika. http://www. lekarzonkolog.pl/publikacje/7135 (data dostępu: 09.02.2016 r.)

8. Markowska J, Markowska A, Mądry R. Marker CA 125 rola w diagnostyce i monitorowaniu raka jajnika. W: Wcisło G, Szczylik C (red.). Rak jajnika. Patobiologia, diagnostyka i przegląd współczesnych metod leczenia. Poznań: Termedia; 2011. 149-152.

9. Basta A i wsp. Rekomendacje Polskiego Towarzystwa Ginekologii Onkologicznej dotyczące diagnostyki i leczenia raka jajnika. Wersja 2015. http://ptgo.pl/rekomendacje-polskiegotowarzystwa-ginekologii-onkologicznej-dotyczace-diagnostyki-i-leczenia-raka-jajnika/ (data dostępu: 17.12.15 r.).

10. Nowak-Markwitz E, Spaczyński M. Nowotwory jajnika, jajowodu i otrzewnej. W: Spaczyński M, Nowak-Markwitz E, Kędzia W (red.). Praktyczna ginekologia onkologiczna. Podręcznik dla lekarzy. Poznań: Wielkopolskie Towarzystwo Onkologii Ginekologicznej; 2012. 122-130. 
11. Rutkowska B, Książek J. Opieka pielęgniarska w chirurgii onkologicznej. W: Koper A (red.). Pielęgniarstwo onkologiczne: podręcznik dla studiów medycznych. Warszawa: PZWL; 2011. 125-136.

12. Kwaśniewska A, Kamusińska E. Rola pielęgniarki w rehabilitacji pacjentów po zabiegach operacyjnych w obrębie jamy brzusznej. Stud Med. 2012; 25 (1): 73-80.

13. Mazur A. Problemy pielęgnacyjne pacjentek z nowotworem narządu rodnego. W: Koper A, Wrońska I (red.). Problemy pielęgnacyjne pacjentów z chorobą nowotworową. Materiały pomocnicze dla pielęgniarek pracujących na oddziałach onkologicznych. Lublin: Czelej; 2003. 41-46.

14. Paszkiewicz-Mes E. Rola pielęgniarki w leczeniu bólu po zabiegu operacyjnym. Pielęg XXI w. 2011; 37 (4): 37-41.

15. Walewska E. Okres okołooperacyjny. W: Czupryna A, Walewska E. (red.). Podstawy pielęgniarstwa chirurgicznego. Warszawa: PZWL; 2007. 106-130.
Artykuł przyjęty do redakcji: 15.07.2016

Artykuł przyjęty do publikacji: 19.08.2016

Źródło finansowania: Praca nie jest finansowana z żadnego źródła. Konflikt interesów: Autorzy deklarują brak konfliktu interesów.

\section{Adres do korespondencji:}

Iwona Włodek

ul. Stanisława Moniuszki 18

05-230 Kobyłka

tel.: 694607323

e-mail: iwona_wlodek@wp.pl

Zakład Podstaw Pielęgniarstwa

Warszawski Uniwersytet Medyczny 